\title{
INDEX OF SUFFIXES
}

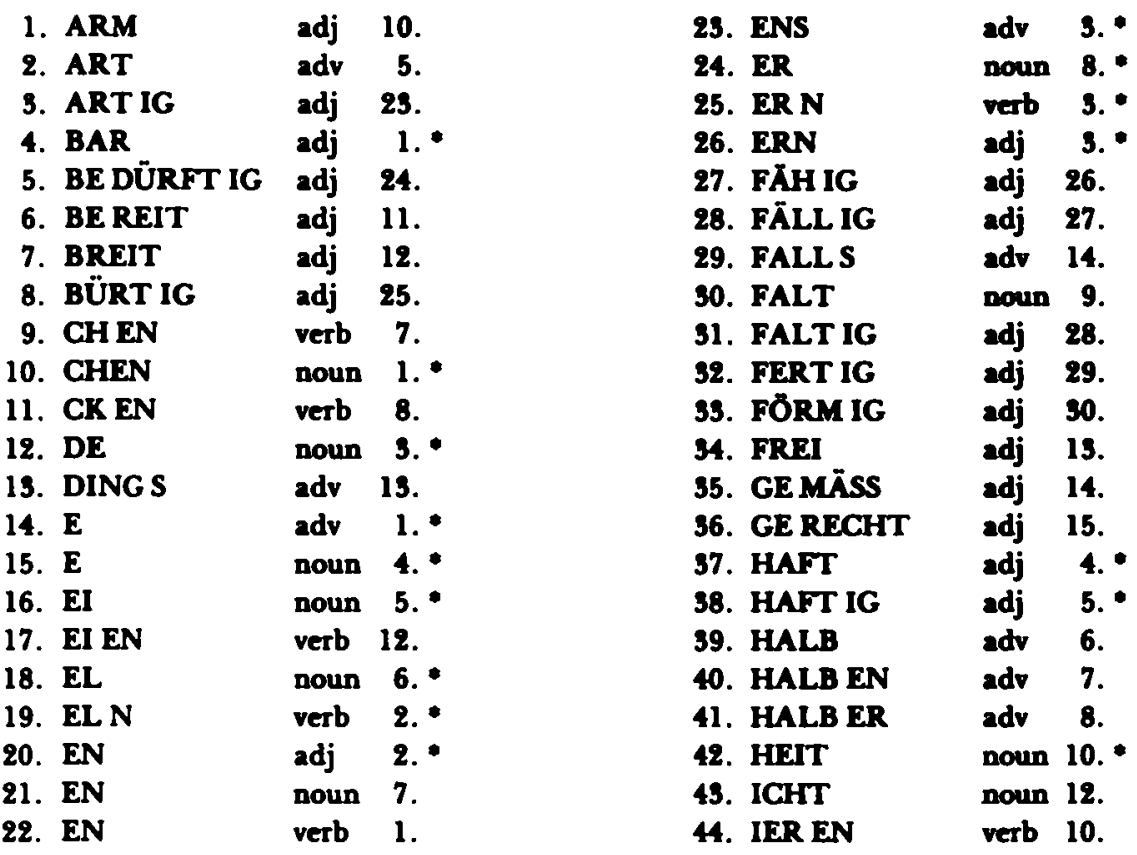


45. IG

46. IN

47. ISCH

48. IS IER EN

49. KEIT

50. LAST IG

51. LEER

52. LEI

53. LEIN

54. LICH

55. LICH

56. LICH EN

57. LING

58. LING S

59. LOS

60. MAL

61. MAL S

62. MASS EN

63. MÄSS IG

64. NIS

65. PF EN

66. RECHT

67. REICH

68. RICH

69. S

70. S

71. SAL adj

6.

noun 13.

adj $7 . *$

verb 11.

noun 11.

adj 31.

adj 16.

adj 17.

noun 2."

adj 8. *

adv 4.

verb 13.

noun 14.

adv 15.

adj 18.

adv 9.

adv 16.

adv 10.

adj 32.

noun 15 .

verb 9.

adj 19.

adj 20 .

noun 16.

adv 2."

noun 17.

noun 18.
72. SAM

73. SCHAFT

74. SCH EN

75. SEIT IG

76. SEIT S

77. SEL

78. S EN

79. ST

80. SÜCHT IG

81. $T$

82. TÜCHT IG

83. TUM

84. UN FXH IG

85. UNG

86. VOLL

87. WÄRT S

88. WEG

89. WEG S

90. WEIL IG

91. WEISE

92. WEND IG

93. WERT

94. WERT IG

95. WID R IG

96. WILL IG

97. WÜRD IG

98. $Z \mathrm{EN}$ adj 9. *

noun 20 ."

verb 6 .

adj 33.

adv 17.

noun 19. *

verb 4.

noun 21 .

adj 34 .

noun 22.

adj 35 .

noun 23. "

adj 36.

noun 24. *

adj 21 .

adv 18.

adv 11.

adv 19.

adj 37 .

adv 12.

adj 38.

adj 22.

adj 39.

adj 40.

adj 41 .

adj 42.

verb 5 .

-Descriptions for the auffixes marted with an ateriak were taken from Herbert Lederer, Refer. ence Gremmer of the German Language (New York: Scribner's, 1969). 


\section{Descruption of Suffixes}

ADJECTIVE-FORMING SUPFIXES

\begin{tabular}{|c|l|l|l|}
\hline SUFFIX & $\begin{array}{l}\text { part of opeech } \\
\text { from which } \\
\text { adjective } \\
\text { is formed }\end{array}$ & examples & how uned/remarks \\
\hline
\end{tabular}

1. BAR

\section{$N$ (mainly)}

V (cometimes)

2. $E N$

$\mathbf{N}$

3. ERN

$\mathbf{N}$

4. HAFT

$\mathbf{N}, \mathbf{A D J}$

5. HAFT IG

N, ADJ

6. IG

$-$ sichtbar, fruchtbar

erfüllbar, unbezahlbar

golden, wollen

hölzern, gläsern, eisern Designates a material.

krankhaft, mädchenhaft

wahrhaftig, leibhaftig

The additional suffix

-IG can be added to -HAFT.

Shows a condition or a similarity (cometimes with Umlaut.)
Designates the type of quality.

the posibility

of s.t. being done.

of a proceas.

Designates a material.

7. ISCH

N, PN (mainly)

arabisch, chemiach, kindiech

V (sometime) malerixch, zeichneriach

Denotes origin, property. or characteristic (often negative: weibiech and kindiech v. weiblich and kindlich.)

8. LICH

freundlich, zerbrechlich, ärgerlich
Denotes characteriatic qualitice (-LICH was originally a noun meaning "body.") 
9. SAM abutract $N, V$, arbeitam, lenkeam,

ADJ langam

The following adjectival suffixes could also be viewed as the second half of a complex (multi-root) stem. The majority of these "suffixes" can also exist as independent words with a generally similar meaning: e.g., ARM, BEREIT, FREI, LEER, VOLL.

10. ARM N

11. BE REIT N

12. BREIT

$\mathbf{N}$

19. FREI

$\mathbf{N}$

14. GE MÃsS

$\mathbf{N}$

15. GE RECHT

16. LEER

$\mathbf{N}$ $\mathbf{N}$

\section{$\mathbf{N}$}

geistarm, blutarm. nikotinarm

startbereit, kampfbereit, abwehrbereit

haarbreit, fingerbreit

bleifrei, sturmfrei, portofrei

standeagemäss, vertragrgemäs, ordnungrgemäs ailgerecht, mundgerecht, formgerecht

geistleer, blutleer, inhaltleer
Expresses the scarcity or minimal presence. Often the source noun expremes elements or ideas. Is often used in pairs with -REICH.

Expreases preparednew or readiness. Often used with nouns of motion (starting and stopping) and with nouns of com. bat and defense.

Expreases width or broadneas.

Expresace freedom from or lack of something. Often used with nouns designating chemical elements, physical obetacles, or financial costs.

Expreses conformity or agreement.

Expreses conformity or agreement.

Expreases absence or void. 
17. LEI

Numerals

18. LOS

N (mainly)

19. RECHT

$\mathbf{N}$ (mainly)

20. REICH

$\mathbf{N}$

N (mainly)

21. VOLL

$$
\text { N (mainly) }
$$

einerlei, zweierlei, alleriei

gedankenlos, wertlos. sinnlos

sentrecht, regelrecht. winkelrecht

geistreich, blutreich, erfolgreich
Forms a series of variative numerals that exprem a number of kinds or types. A linking -ERis ueed.

Expresuce the abuence of a quality. It is often a negative member in pairs with - VOLL.

Exprewes either a geometric relationship of right angles or a relationship of conformity.

Expresues fullnes, richnese or abundance. Corresponds to Englinh -FULL. Is often used in pairs with -ARM.

gedankenvoll, wertvoll, Expremes fullneas. Is sinnvoll often used in pain with -LOS or cometimes -FREI.

sehenowert, bemerkens- This suffix is uoually atwert, empfehlenswert tached to a noun which has been formed by the ouffix -EN or -UNG, and which itwelf is derived from a verb. The suffix indicates that the source action is worthy or valu. able.

The following series of suffixes ending in -IG are really compounds in which the real suffix is -IG, which is added to a complex (multi-root) stem: thus, affenartig is really Affenart + ig, not Affen + artig. 
23. ART IG N, ADJ

24. BE DÜRF N T IG

25. BÜRT IG

ADJ

26. FÄH IG N

27. FÄLL IG $N, V$

28. FALT IG Numerals

29. FERT IG N

30. FO̊RM IG N

31. LAST IG N

32. MĀsS IG N aalartig, fremdartig. gromartig

liebesbedürtig. erbolungabedürtig

ebenbürtig, vollbürtig, Expreses a relationship edelbürtig of birth, parentage, or rank.

arbeitufăhig, kampf- Expresses the capability fahig, zahlungatahig or ability to do something.

bauflllig, schwerfallig, The original idea is "to otraffallig

fall." Expreses the related ideas of heaviness, or susceptibility or liability.

dreifaltig, hundert- Corresponds to English faltig "-FOLD". Used with individual numbers to designate a specific number of times.

kampffertig, schlünel- Expreses a readinew or fertig; schlagfertig preparednes.

lueiförmig, bohnen- Expreases similarity of formig form or ahape.

kopflactig. echwanzlas- Exprenes burden or tig. steuerlastig weight.

vernunftumänig, bei- Expreases the idea of spielmäxig, regelmä- moderatenew or fitnew. is Can also be uned to show the clone relationahip or "use" of the stem-noun. 
33. SEIT IG

ADJ, Numerals

$$
\text { gleicheritig }
$$

34. SÜCHT IG V; rome ADJ and $N$

35. TÜCHT IG $\mathbf{N}$

36. UN FÄH N IG

37. WEIL IG ADJ, $N$

38. WEND IG ADJ, $\mathbf{N}$

39. WERT IG ADJ, Numerals

40. WID R IG N

41. WILL IG N, ADJ

42. WÜRD IG N, V(cometime) eifensüchtig, habsüchtig, selbetsüchtig

geschäftutüchtig

arbeitsunfahig. kampfunfthig. zahlungsunfahig

zeitweilig, langweilig

notwendig

vollwertig, minderwertig

folgewidrig, verkehrowidrig
Expremes the number or type of sides or directions.

Expresses a craving or addiction or preoccupation.

Expresea capability, suitability, or akill.

Used in a small number of words that expreas the oppocite of FXHIG: the inability or incapability of doing comething.

Expreaces duration of time.

Exprewes a reciprocal or inteneive relationship.

Exprewes worth or value.

Exprewera an adverne or contrary relationship.

Often associated with the English prefix "COUNTER-".

Expremes willingneas, readiness, or docility.

Expresues worth or de. servedness. Often occurs with prefixed nouns ending in -UNG. 
ADVERB-FORMEG SUFPLES

\begin{tabular}{|c|l|l|l|}
\hline SUFFIX & $\begin{array}{l}\text { part of opeech } \\
\text { from which } \\
\text { adverb } \\
\text { is formed }\end{array}$ & examples & how ured/remarks \\
\hline
\end{tabular}

1. E

ADJ

lange, atille, balde

Many of these words are either obsolescent or have become colloquial. They still frequently occur in poetic ueage.

2. S N, ADJ tags, rechts;

3. ENS N, ADJ meistens, erutens

The $\cdot \mathbf{S}$ is originally the genitive ending of masc. or neuter nouns. By analogy it can occur with feminine nouns (nachts.)

4. LICH ADJ

freilich, kürzlich, sich. In Engtich the cognate erlich adverbial ending - LY is vastly more productive. In German there are only a few words that are exclusively adverbs which are formed with - LICH.

The following adverbial suffixes could also be viewed as the second half of a complex (multi-root) stem. The majority of these "suffixes" can also exist as independent words with a generally similar meaning: e.g., ART, MAL, WEG, WEISE.

5. ART ADJ, Article derart, welcherart,
allerart

Expresues extent or means. Used only with der, welcher, solcher, aller. 
6. HALB

Article,

deahalb, dieserhalb

Demonstrative

Exprewes "for the sake

PN

of."

7. HALB EN

Pronoun-

meinethalben,

Adjective;

Article

deinethalben

Expreases "for the sake of."

8. HALB ER N

geaundheitahalber, ansandshalber

Expresices "for the sake of": a reason or an intended benefit.

9. MAL

Numbers

einmal, zehnmal, hundertmal

Expresses the number of times comething has happened.

10. MASS EN ADJ

einigermasen, gewis- Expresecs extent or maneermassen, verner. A linking - ER - is sprochenermamen used.

11. WEG

AD]

frischweg, glattweg.

Denotes manner.

kurzweg

12. WEISE $N, A D J$

paarweise, stufenweise, Denotes manner. auenahmoweise

The following series of suffixes ending in $-S$ could also be intepreted as compounds in which the real suffix is only $-\mathrm{S}$, which is added to a complex (multi-root) stem: thus, jedenfalls could be considered to be jeden + fall $+s$ as well as jeden + falls.

13. DINGS ADJ allerdings, neuerdings

Uned with ALL, NEU, SCHLECHT, GLATT, PLATT. An intenification force is often present. A linking -ER- is used.

14. FALLS ADJ

gieichfalls, jedenfalls 
preases the idea of way, event, case, or eventuality.

15. LING S N, ADJ, V, bäuchlings, rücłlings,

Denotes manner. IndiADV. Preposi- blindlings cates position or directions tion toward something. (Usually with umlaut)

16. MALS ADJ damals, vielmals, mehrmals

Denotes time or number of times.

17. SEIT $S$ N

1. väterlicherseits,

1. Expresses side. linkerseits

Pronoun-

Adjective

2. meinerseits, seinerseits

2. Expreses a personal reference or viewpoint.

18. WÄRTS N(mainly) vorwärts, outwärts, heimwärts

Denotes direction toward. Corresponds to the English - WARD.

19. WEGS

Denotes manner.

NOUN-FORMNG SUFFIXES

\begin{tabular}{|c|c|c|c|c|}
\hline SUFFIX & gender & $\begin{array}{l}\text { part of } \\
\text { tpeech } \\
\text { from } \\
\text { which } \\
\text { noun is } \\
\text { formed }\end{array}$ & examples & how used/remarts \\
\hline 1. CHEN & Neut & $\mathbf{N}$ & $\begin{array}{l}\text { Städtchen, } \\
\text { Mridchen }\end{array}$ & $\begin{array}{l}\text { Forms diminutives } \\
\text { (urally with umlaut). }\end{array}$ \\
\hline 2. LEIN & Neut & $\mathbf{N}$ & $\begin{array}{l}\text { Schneiderlein, } \\
\text { Brüderlein }\end{array}$ & $\begin{array}{l}\text { Forms diminutives } \\
\text { (usually with umlaut). }\end{array}$ \\
\hline
\end{tabular}


3. DE Fem + Neut V Freude, Gebäude

4. E Fem Vor Hilfe, Bitte Often with umlaut or Adj vowel change.

Säge, Winde Often derignates tool or instruments.

5. EI

Fem

V or $\mathbf{N}$ Zauberei,

Schreiberei

An intensive activity, sometimes with a derogatory connotation.

Bücherei, A place of busines, Molkerei occupation, or activity.

6. EL

Masc (mainly) V
Fem
(occasionally)

Hebel, Flügel

Often indicates tools or instruments.

7. $\mathrm{EN}$

Masc (mainly) - $\quad \begin{aligned} & \text { See below for } \\ & \text { Fem } \\ & \text { (occasionally) }\end{aligned}$

This suffix has no appreciable meaning. It is used with words that denote: an instrument (Spaten, Bogen, Haken); a place for storing or securing s.t. (Laden, Schuppen, Hafen); a part of the body (Magen, Rücken, Daumen); in some cases an abstract idea (Glaube(n), Friede(n), Schreck/Schrecken). As an infinitive ending it can be used as a nominalization of most verbs (das Treiben, das Tun, das Sprechen). This is a mechanical application of a grammatical process, and all cases of infinitive used as noun are neuter.

8. $\mathbf{E R}$

$\begin{array}{cll}\text { Masc } & \mathbf{V} & \text { Verkäufer, } \\ & \text { (mainly) } & \begin{array}{l}\text { Schneider } \\ \text { Bettler, }\end{array} \\ & \text { Holländer }\end{array}$

Deaignates occupations (umlaut). Characterizes person by a particular attribute or place of origin. 
9. FALT

10. HEIT

11. KEIT

12. ICHT

13. IN

14. LING

Masc

15. NIS

16. RICH

Fem

Fem

Neut

Fem

Masc
Numeral N

Masc N Freundin,

Königin

V, Adj, Lehrling other $\mathbf{N}$ Strafling

Schwilchling.

Bitterling

Frïhling,

Silberling

Neut or Fem V, Adj, Gefingnis, other N Finsternis
$\mathbf{N}$
Enterich, Ganserich
Corresponds to Engliah "FOLD."

A condition or a characteritic.

A condition or a characterintic. Used after the suffixes BAR, IG. LICH, SAM, and often after EL and ER.

A collective idea (Kehricht) or a collection or gathering of plants.

Indicates a female counterpart.

Deacribes a pernon by means of the condition or activity in which he finds himcelf. (Usually with umlaut.)

Often diminutive or atrongly pejorative. Some older formations are impersonal.

Devignates actions, conditions, or thinge.

Original meaning was "ruler." Present use is greatly weakened in force from "ruler." Is ueed to designate the 
Weiderich,

Hederich

17. $S$

Masc

$\mathbf{v}$

Knick, Klape,

Schnape. Schwipe

18. SAL

Neut

v

Schickeal,

(mainly) (mainly) Trübeal

19. SEL

Neut

v

Mitbringrel,

(mainly)

(mainly) Überbleibeel

20. SCHAFT Fem

N
(mainly)
Adj
and
Parti-
ciples
(come-
times)

Grafuchaft.

Collective nouns that

male of ecveral specica of birds. It can aloo be ued for certain plants.

21. ST

all genders

v

der Gewinet, das Gespinat, die Kunat (können) designate territory, a group, a condition, or a property. Lehrenchaft, Verwandtechaft

22. $T$

Fem

v

Fahrt, Wacht.

Tracht

23. TUM

Neut

(mainly)

Fürotentum.

Bürgertum

Reichtum,

Irrtum

$\begin{array}{ll}\text { V } & \text { Haltung, } \\ \text { (often } & \text { Vorausetzung, } \\ \text { verbs) } & \text { Mitteilung } \\ \text { with } & \\ \text { prefixes) } & \end{array}$

Forms abetract nouns.

Designates territory or group.

May aleo show abetract qualities.

A very widely ued suffix.

24. UNG

Fem 
VERE-FORMING SUFFIXES

\begin{tabular}{|c|l|l|l|}
\hline SUFFIX & $\begin{array}{l}\text { part of speech } \\
\text { from which } \\
\text { verb is formed }\end{array}$ & examples & how used/remarks \\
\hline
\end{tabular}

1. $\mathbf{E N}$

- haben, sehen, gehen

This is by far the most frequent infinitive suffix for German verbs. Indeed, with very few exceptions, all German infinitives are formed with either -EN, -ELN. or -ERN.

The infinitive suffix (-EN, -ELN, -ERN, etc.) is the same suffix that is used for the first and third plural endings (wir haben, sie haben) as well as for the polite/formal singular and plural endings (Sie haben) of verbs.

2. ELN

betteln, streicheln
prasaeln, zappeln
lächeln, tröpfeln
schmeicheln, heucheln.
klügeln
Es füchøelt, anbeimeln

1. Iteration: the frequent occurrence and repetition of an activity.

2. Rapidity.

3. Diminutive force.

4. Depreciatory force.

5. Likenes, aimilarity, close anociation.
3. ERN
- schnattern, stottern, flackern

1. Frequent repetition or continuation of an action, often in jerls or in an unsteady motion. 
mich «chlžfert, trinkert, durntert

4. SEN

5. $2 \mathrm{EN}$

6. SCHEN

7. CHEN

8. CKEN

9. PFEN

10. IEREN

japeen, knipsen,
klecksen, mucksen
- lechzen, jauchzen,
grunzen

- quietschen, löachen

V horchen $\leftarrow$ hören

V bücken $\leftarrow$ biegen

V rupfen $\leftarrow$ raufen

$\mathbf{N}$ (frequently) marachieren, buchstabieren, halbieren
2. The irreacible deaire of doing that which is implied in the stem. Especially frequent in impersonal constructions. (Obnolete)

Iterative force and weak diminutive force.

Iterative force and weak diminutive force.

Iterative force and weak diminutive force.

This is actually the strengthening of the final consonant of the stem, and expresses an intensification of the meaning of the stem.

This is actually the trengthening of the final coneonant of the atem, and exprewers an intensification of the meaning of the stem.

This is actually the atrengthening of the final coneonant of the atem, and expreseses an intenvification of the meaning of the stem.

This suffix has no distinct meaning. It was originally a French ending, but is now 
aficixed to German as well as to foreign

stems.

11. ISIEREN

12. EIEN

13. LICHEN
N prophezeien, benedeien, (frequently) maledeien

ADJ verehelichen, verinnlichen, ermöglichen
This suffix correaponds to a great extent to the English suffix -IZE.

This suffix has no distinct meaning. It often corresponds to the foreign ending - $\mathrm{EI}$ in nouns.

This often corresponds to an adjective ending in - LICH. The verb is usually prefixed, and is transitive. 